\title{
PERBANDINGAN KUALITAS ROTI BUN DENGAN PENGGUNAAN ADONAN ASAM DARI RAGI SARI MENTIMUN DAN SARI CIREMAI
}

\author{
Ridawati $^{1)}$ dan Alsuhendra ${ }^{2}$ \\ ${ }^{1,2}$ Program Studi Pendidikan Tata Boga, Fakultas Teknik, Universitas Negeri Jakarta, \\ 1,2Jalan Rawamangun Muka, Jakarta Timur, 13220 \\ E-mail : ridawati.sesil@gmail.com ${ }^{1)}$, alsuhendra@gmail.com ${ }^{2)}$
}

\begin{abstract}
ABSTRAK
Adonan asam merupakan adonan yang diolah menggunakan mikroba alami yang terdapat dalam bahan dasar produk pangan, seperti tepung terigu dan sari buah yang digunakan sebagai sumber mikroba. Tujuan penelitian ini adalah untuk membandingkan kualitas zat gizi dan kualitas organoleptik roti bun yang diolah menggunakan adonan asam dari ragi sari mentimun dan sari ciremai. Penelitian ini menggunakan metode eksperimen dengan perlakuan perbedaan sumber ragi yang digunakan yaitu ragi dari sari mentimun dan ragi dari sari ciremai. Penelitian dilakukan duplo dengan dua kali ulangan. Analisis zat gizi roti bun meliputi analisis kadar air, kadar abu, kadar protein dan kadar lemak serta kadar karbohidrat (by difference). Analisis organoleptik dilakukan menggunakan uji mutu hedonik terhadap aroma, penampakan, rasa dan tekstur dengan 9 skala penilaian dan dilakukan oleh 9 panelis terlatih. Hasil uji kadar zat gizi dan kualitas organoleptik dari roti bun dianalisis menggunakan uji t-test paired two sample for mean. Roti bun yang diolah menggunakan ragi sari mentimun memiliki rata-rata kadar air 35,85\%, kadar abu 0,69\%, kadar protein 9,80\%, kadar lemak $3,49 \%$ dan karbohidrat $50,16 \%$, sedangkan roti bun yang diolah menggunakan ragi sari ciremai memiliki rata-rata kadar air $35,70 \%$, kadar abu $0,83 \%$, kadar protein 9,74\%, kadar lemak 2,56\% dan karbohidrat 51,17\%. Kadar zat gizi roti bun yang diolah menggunakan adonan asam dari ragi sari mentimun dan sari ciremai menunjukkan hasil uji hipotesis statistik signifikan tidak berbeda nyata $(\alpha=0,05)$. Secara statistik hasil uji organoleptik pada tingkat kesalahan 0,05 tidak menunjukkan hasil yang berbeda nyata pada aspek aroma, penampakan, rasa dan tekstur dari roti bun yang diolah menggunakan adonan asam dari ragi sari mentimun dan sari ciremai.
\end{abstract}

Kata Kunci: Roti Bun, Adonan Asam, Mentimun, Ciremai, Organoleptik, Zat Gizi

\section{PENDAHULUAN}

Penelitian roti sebagian besar terfokus pada penelitian jenis, formulasi dan variasi penggunaan tepung pada pembuatan roti dengan substitusi tepung pada pembuatan roti dengan variasi roti yang diteliti adalah roti tawar dan roti manis. Penggunaan beberapa campuran tepung atau tepung komposit pada pembuatan roti juga telah dilakukan (Bhatt dan Gupta, 2015).

Beberapa penelitian roti menggunakan bahan substitusi tepung umbi seperti tepung singkong, tepung ubi ungu, dan tepung kedelai juga telah dilaporkan beberapa peneliti (Wulandari, 2017; Ayele dkk., 2017). Tepung umbi lainnya yang dilaporkan dapat disubstitusi pada pembuatan roti adalah tepung umbi kentang. Pengembangan produk roti menggunakan tepung bebas gluten juga banyak dilakukan. Beberapa bahan yang dilaporkan telah digunakan dalam pembuatan roti untuk menggantikan terigu adalah pembuatan roti tawar bebas gluten berbahan baku tepung garut, tepung beras, dan maizena (Muthoharoh dan dan Sutrisno, 2017).

Penggunaan tepung garut, tepung beras, dan maizena sebagai bahan baku roti diharapkan memiliki kemampuan menahan gas CO2. Penambahan glukomanan tidak memberikan pengaruh nyata terhadap volume pengembangan adonan, tetapi waktu proofing berpengaruh nyata terhadap volume pengembangan adonan dan volume pengembangan spesifik. Perlakuan terbaik pembuatan roti dari tepung garut, tepung beras, dan maizena yaitu dengan penambahan glukomanan pada konsentrasi $0,5 \%$ dengan waktu proofing 60 menit (Muthoharoh dan dan Sutrisno, 2017).

Hingga saat ini beberapa penelitian tentang ragi yang digunakan sebagai starter dalam pembuatan roti telah banyak dilaporkan. Jenis ragi yang digunakan dalam pembuatan roti merupakan salah satu bahan yang juga mempengaruhi kualitas roti yang dihasilkan. Penggunaan ragi roti dan adonan asam pada pembuatan roti menentukan profil metabolit yang dihasilkan selama proses fermentasi seperti dilaporkan oleh (Koistinen dkk., 2018). Pengaruh penggunaan mikroba starter dari tepung terigu yang digunakan pada pembuatan adonan asam juga dilaporkan oleh (Koistinen dkk., 2018).

Salah satu teknik dalam pembuatan roti adalah pembentukan adonan asam (sourdough). Metode adonan asam adalah metode dalam membuat roti dengan memanfaatkan ragi dari khamir yang secara alami terdapat pada tepung seperti Candida milleri dan Lactobacillus. 
Sebelumnya peneliti lain melaporkan penggunaan isolat khamir yang berasal dari berbagai buah-buahan lokal Malaysia pulp inti sawit (Cocos nucifera L.), lengkeng (Dimocarpus longan spp.), sirsak (Annona muricata L.), rebung (Bambusa vulgaris), buah salak (Salacca zalacca) dan mangga (Mangifera indica) pada pembuatan roti (Ma'aruf dkk., 2011). Peneliti lain melaporkan penggunaan metode adonan asam pada pembuatan roti dari tepung beras dan menghasilkan karakteristik yang berbeda dari roti bebas gluten (Therdthai, 2015).

Penggunaan mikroba dari susu kefir sebagai mikroba tambahan pada pembuatan adonan juga dilaporkan oleh (Mansooreh dkk., 2017). Susu kefir merupakan susu fermentasi menggunakan biji kefir yang mengandung khamir dan bakteri asam laktat. Penggunaan susu kefir dalam pembuatan roti dengan modifikasi dalam teknik fermentasi dapat meningkatkan kualitas roti dan umur simpan.

Modifikasi penggunaan mikroba campuran dalam pembuatan roti dapat menghasilkan roti dengan kualitas yang berbeda. Ekstrak buah dan sayur dapat digunakan sebagai media alami pertumbuhan khamir secara spontan. Hasil penelitian sebelumnya telah melaporkan mikroba dominan yang diperoleh dari ekstrak buahbuahan yaitu khamir Saccharomyces cerevisiae (Ma'aruf dkk., 2011). Buah-buahan lokal Indonesia seperti buah ciremai dan mentimun juga diduga juga memiliki potensi sebagai starter alami adonan asam pada pembuatan roti.

Buah mentimun dan ciremai merupakan ekstrak yang memiliki potensi untuk dikembangkan sebagai ragi alami pada pembuatan roti. Mentimun merupakan salah satu sayuran buah yang banyak dikonsumsi masyarakat Indonesia dalam bentuk segar. Buah mentimun memiliki kadar air 96\%, kadar abu 0,4-0,6\%, kadar lemak 0,25\%, kadar protein 0,29-0,84\%, kadar karbohidrat 1,89-2,63\%, serta kaya akan mineral potasium, kalsium, tembaga, magnesium, mangan, sodium dan seng (Bw dkk., 2017).

Buah ciremai tumbuh secara bergerombol mirip cara tumbuh buah anggur, tetapi ciremai sebenarnya termasuk dalam jenis buah berry. Buah ciremai memiliki rasa masam yang kuat saat masih muda tapi akan mejadi manis setelah matang. Salah satu kelebihan buah cermai adalah nutrisinya yang cukup lengkap. Buah ciremai memiliki kadar air 85,06\%, kadar abu 1,54\%, kadar protein $0.7 \%$, kadar lemak $0,11 \%$, kadar serat $2,74 \%$, keasaman 2,54\%, asam askorbat 430,1 mg/100g (Goraya dan Bajwa, 2015). Peneliti lain melaporkan komposisi buah ciremai segar memiliki kadar air $85 \%$, kadar abu $0,6 \%$, kadar protein 0,615, kadar lemak 0,13\% dan keasaman 1,75\% (Survase dkk., 2018). Sari buah mentimun dan ciremai merupakan bahan yang memiliki potensi untuk digunakan sebagai media alami pertumbuhan khamir untuk pembuatan starter adonan asam pada proses pembuatan roti bun.

Roti bun merupakan salah satu jenis roti manis berbentuk bulat atau lonjong pipih, dan digunakan sebagai wadah untuk daging burger ataupun sosis.
Penelitian ini bertujuan untuk menganalisis perbandingan kualitas zat gizi dan kualitas organoleptik roti bun yang diolah menggunakan adonan asam dari ragi sari mentimun dan sari ciremai.

\section{RUANG LINGKUP}

Dalam penelitian ini permasalahan mencakup formulasi adonan roti dengan menggunakan starter ragi dari sari ciremai dan sari mentimun. Penelitian dibatasi pada analisis kandungan zat gizi meliputi kadar air, kadar abu, kadar lemak, kadar protein dan karbohidrat (by difference) dan analisis organoleptik mutu hedonik. Hasil yang diperoleh direncanakan berupa kandungan zat gizi dan hasil analisis kualitas organoleptik dari roti bun yang diolah menggunakan metode adonan asam ragi sari mentimun dan sari ciremai.

\section{BAHAN DAN METODE}

Bahan yang digunakan pada penelitian ini adalah bahan utama yang terdiri dari buah mentimun, buah ciremai, tepung terigu dan gula pasir. Buah mentimun dan buah ciremai diperoleh dari pasar di daerah Jakarta Timur. Bahan tambahan lainnya adalah bahan pembuatan roti seperti margarin, susu bubuk, telur, bread improver, garam, dan bahan isi, serta bahan analisis kadar protein dan kadar lemak. Alat yang dibutuhkan pada penelitian ini adalah alat untuk pembuatan starter ragi, alat pembuatan adonan roti, oven roti, oven memmert, tanur, labu soxhlet, dan macro kjeldahl.

Metode penelitian dibagi menjadi beberapa tahap yaitu pembuatan ragi sari buah, pembuatan adonan asam, pembuatan roti bun, analisis zat gizi dan analisis organoleptik.

\subsection{Metode Pembuatan Ragi Sari Buah}

Pembuatan ragi sari buah mengacu pada prosedur pembuatan starter yang disajikan pada gambar 1 . Proses pembuatan dilakukan secara aseptis yang didahului dengan menyortir dan mencuci buah, dilanjutkan dengan proses penghalusan dan inkubasi selama 48 jam.

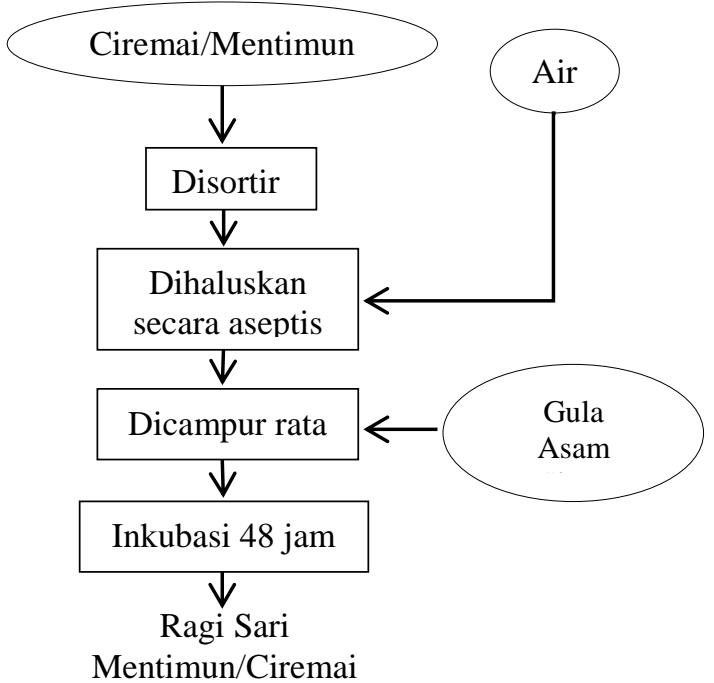

Gambar 1. Proses Pembuatan Ragi Sari Buah 
Formula untuk pembuatan ragi sari buah mengacu pada formula yang disajikan pada tabel 1. Formula dihitung dengan menggunakan Baker's persencetage, yaitu persentase yang didasarkan pada berat bahan baku utama (buah).

Tabel 1. Formula Ragi Sari Buah

\begin{tabular}{|c|l|c|}
\hline No & \multicolumn{1}{|c|}{ Nama Bahan } & Jumlah (\%) \\
\hline 1 & Buah & 100 \\
\hline 2 & Air & 100 \\
\hline 3 & Gula Pasir & 15 \\
\hline 4 & Asam Sitrat & 1 \\
\hline
\end{tabular}

\subsection{Metode Pembuatan Adonan Asam}

Pembuatan adonan asam menggunakan ragi sari ciremai/mentimun. Bahan lain yang ditambahkan adalah tepung terigu protein tinggi dan gula pasir yaitu formula adonan asam A. Adonan A diinkubasi selama 24 jam hingga diperoleh adonan asam A. Formula yang digunakan pada pembuatan adonan asam dapat dilihat pada tabel 2 .

Tabel 2. Formula Adonan Asam A

\begin{tabular}{|l|l|c|}
\hline No & \multicolumn{1}{|c|}{ Nama Bahan } & Jumlah (\%) \\
\hline 1 & Ragi Sari Ciremai/Mentimun & 100 \\
\hline 2 & Tepung Terigu Protein Tinggi & 100 \\
\hline 3 & Gula Pasir & 15 \\
\hline
\end{tabular}

Formula adonan asam B terdiri dari adonan asam A ditambah dengan air steril dan tepung terigu protein tinggi dengan perbandingan 1:1:1 untuk setiap bahannya dapat dilihat pada tabel 3. Adonan B diinkubasi selama 20 jam hingga diperoleh adonan asam $B$.

Tabel 3. Formula Adonan Asam B

\begin{tabular}{|l|l|c|}
\hline No & \multicolumn{1}{|c|}{ Nama Bahan } & Jumlah (\%) \\
\hline 1 & Adonan Asam A & 100 \\
\hline 2 & Air & 100 \\
\hline 3 & Tepung Terigu Protein Tinggi & 100 \\
\hline
\end{tabular}

Setelah adonan asam B diperoleh dilanjutkan dengan pembuatan adonan asam $\mathrm{C}$ dengan formula pada tabel 4 . Formula adonan asam $\mathrm{C}$ terdiri dari adonan asam $\mathrm{B}$ ditambah dengan air steril dan tepung terigu protein tinggi dengan perbandingan 1:1:1 untuk setiap bahannya. Adonan $\mathrm{C}$ diinkubasi selama 20 jam hingga diperoleh adonan asam $\mathrm{C}$.

Tabel 4. Formula Adonan Asam C

\begin{tabular}{|l|l|c|}
\hline No & \multicolumn{1}{|c|}{ Nama Bahan } & Jumlah (\%) \\
\hline 1 & Adonan Asam B & 100 \\
\hline 2 & Air & 100 \\
\hline 3 & Tepung Terigu Protein Tinggi & 100 \\
\hline
\end{tabular}

Prosedur pembuatan adonan asam A, adonan asam B dan adonan asam $\mathrm{C}$ dilakukan secara aseptis seperti pada gambar 2. Proses pembuatan adonan meliputi proses pencampuran dan inkubasi. Lama inkubasi untuk setiap adonan ditentukan berdasarkan hasil pengamatan terhadap kemampuan adonan asam mengembang.

Adonan asam $\mathrm{C}$ merupakan adonan asam yang selanjutnya digunakan sebagai starter pada pembuatan adonan roti bun.
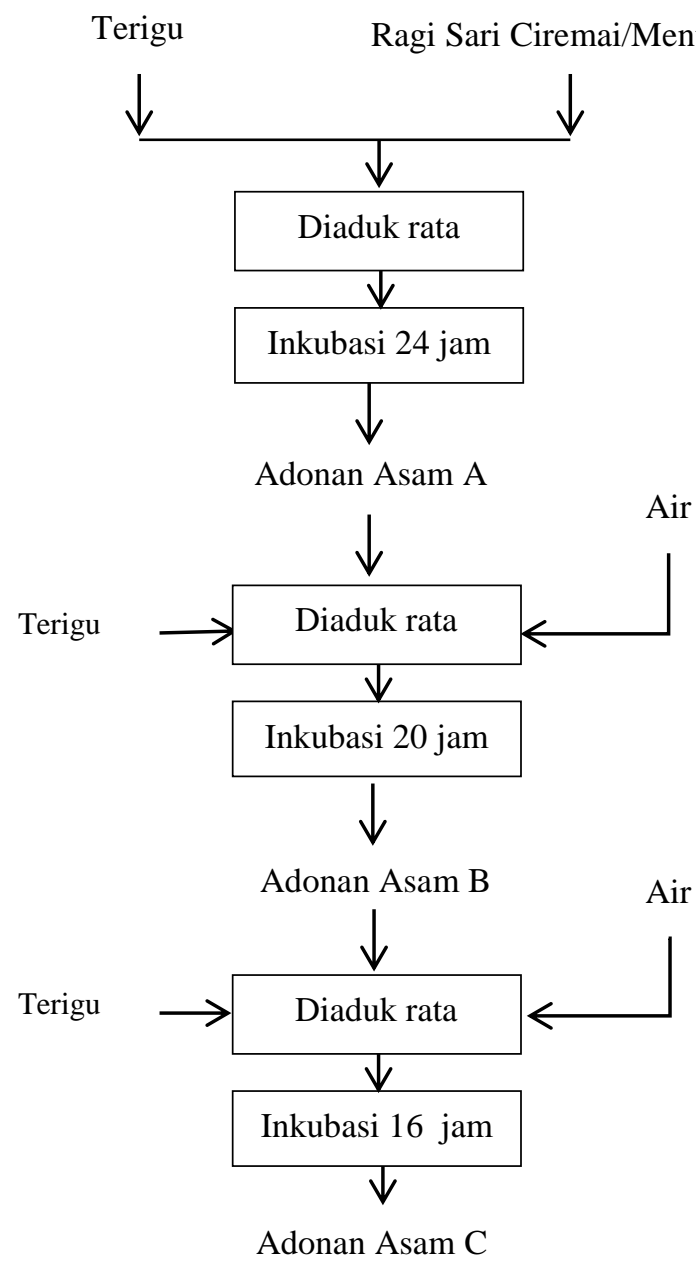

Gambar 2. Proses Pembuatan Adonan Asam

\subsection{Metode Pembuatan Roti Bun}

Roti manis dibuat dengan menggunakan adonan asam $\mathrm{C}$ sebagai ragi dan penambahan tepung terigu, gula pasir, bread improver, susu bubuk, telur, air dan margarin seperti disajikan pada tabel 5 .

Tabel 5. Formula Adonan Roti Bun

\begin{tabular}{|l|l|c|}
\hline No & \multicolumn{1}{|c|}{ Nama Bahan } & Jumlah (\%) \\
\hline 1 & Adonan Asam C & 100 \\
\hline 2 & Tepung Terigu Protein Tinggi & 200 \\
\hline 3 & Gula Pasir & 50 \\
\hline 4 & Bread Improver & 1 \\
\hline 5 & Susu Bubuk & 15 \\
\hline 6 & Telur & 40 \\
\hline 7 & Air & 100 \\
\hline 8 & Margarin & 50 \\
\hline
\end{tabular}


Proses pembuatan Roti bun diawali dengan penimbangan bahan. Bahan-bahan yang telah disiapkan harus ditimbang secara tepat sehingga dapat memberikan formula dan hasil produk roti bun yang baik. Bahanbahan yang telah ditimbang kemudian dicampur. Bahan kering dicampur terlebih dahulu dan aduk hingga merata, lalu dimasukkan bahan basah. Selanjutnya dilakukan pengadukan adonan menggunakan mixer hingga kalis. Pengistirahatan adonan pertama selama 3 jam. Jika adonan sudah mengembang dua kali lebih besar, fermentasi dapat dihentikan, kemudian dilakukan potong dan timbang adonan dengan berat 50 gram. Adonan yang telah dipotong dan ditimbang dibulatkan kembali untuk kembali diistirahatkan. Waktu yang dibutuhkan untuk mengistirahatkan adonan kedua lebih singkat dibanding pengistirahatan adonan tahap pertama, yaitu 2 jam. Setelah pengistirahatan tahap kedua, buang gas pada adonan dengan cara ditekan-tekan. Selanjutnya dilakukan tahap pembentukan dan pengisian adonan. Letakkan adonan pada loyang dan di olesi dengan campuran kuning telur dan susu untuk mendapatkan warna kecoklatan, aroma susu, dan rasa gurih pada kulit atas roti. Adonan roti yang sudah diletakan di atas loyang kemudian didiamkan terlebih dahulu selama 30 menit sebelum dioven. Adonan ditutupi menggunakan plastik. Pembakaran berlangsung selama 15 menit pada suhu oven $200^{\circ} \mathrm{C}$. Setelah proses pemanggangan selesai, roti dikeluarkan dan didiamkan hingga dingin. Selanjutnya produk dikemas menggunakan plastik kedap udara dan siap dianalisis.

\subsection{Metode Analisis Zat Gizi}

Analisis kadar air, kadar abu, kadar protein dan kadar lemak dilakukan menggunakan metode yang (Yenrina, 2015). Kadar air adalah persentase kandungan air suatu bahan yang dapat dinyatakan berdasarkan berat basah. Kadar air berdasarkan berat basah adalah perbandingan antara berat air dalam suatu bahan dengan berat total bahan. Kadar abu bahan yang merupakan sisa pembakaran dalam tanur dengan menggunakan suhu $500^{\circ} \mathrm{C}$. Penentuan kadar protein kasar dengan metode makro kjedahl terdiri dari proses destruksi, destilasi dan titrasi. Kandungan nitrogen dalam bahan ditentukan dengan cara kjedahl, yang hasilnya dikalikan dengan faktor koreksi 6,25. Kadar lemak ditentukan dengan cara ekstraksi bahan dalam pelarut organik menggunakan heksan. Penghitungan kadar karbohidrat total dalam sampel dihitung berdasarkan perhitungan (dalam \%) yaitu $100 \%$ dikurangi jumlah persen protein, lemak, abu, dan air . Uji dilakukan dua kali ulangan duplo.

\subsection{Metode Analisis Organoleptik}

Analisis mutu hedonik menggunakan analisis mutu hedonik roti yang dimodifikasi dengan 9 skala penilaian, meliputi aspek aroma, penampakan, rasa dan tekstur dan dilakukan oleh 9 orang panelis terlatih (Lombardi dan Pecorino, 2016) .

\section{PEMBAHASAN}

Cairan yang diperoleh dari hasil fermentasi sari buah mentimun dan ciremai merupakan bahan cair yang mengandung khamir dengan karakteristik cairan memiliki aroma seperti aroma tapai, rasa agak asam, warna keruh dan agak kental. Setelah disaring cairan digunakan sebagai starter untuk pembuatan adonan asam. Adonan asam dibuat dalam tiga tahap sehingga diperoleh adonan asam $\mathrm{C}$ yang siap untuk dijadikan sebagai bahan dasar formula roti yaitu adonan yang memiliki kemampuan untuk mengembangkan adonan roti dengan baik. pembuatan adonan asam dilakukan agar adonan menjadi adonan yang memiliki kemampuan untuk menangkap atau menghasilkan gas sehingga adonan roti dapat menjadi lebih berongga. Adonan asam dari starter sari ciremai dan sari mentimun selanjutnya digunakan dalam pembuatan adonan roti bun (Chavan dan Chavan, 2011).

Roti bun yang diolah dengan menggunakan adonan asam ragi sari mentimun dan sari ciremai dan dianalisis kadar zat gizi dan kualitas organoleptiknya. Hasil analisis kadar air, kadar abu, kadar protein dan kadar lemak serta karbohidrat roti bun disajikan pada tabel 6 .

Tabel 6. Hasil Analisis Zat Gizi Roti Bun yang Diolah dengan Adonan Asam Ragi Sari Mentimun (M) dan Sari Ciremai (C)

\begin{tabular}{|l|l|c|c|}
\hline \multirow{2}{*}{ No } & \multirow{2}{*}{ Komponen } & \multicolumn{2}{|c|}{ Kadar $(\%)$ bahan } \\
\cline { 3 - 4 } & & $\mathrm{M}$ & $\mathrm{C}$ \\
\hline 1 & Kadar Air & $35,85 \pm 0,69$ & $35,70 \pm 0,83$ \\
\hline 2 & Kadar Abu & $0,69 \pm 0,005$ & $0,83 \pm 0,19$ \\
\hline 3 & Kadar Protein & $9,80 \pm 0,03$ & $9,74 \pm 0,14$ \\
\hline 4 & Kadar Lemak & $3,49 \pm 0,13$ & $2,56 \pm 0,21$ \\
\hline 5 & $\begin{array}{l}\text { Karbohidrat } \\
\text { (by difference) }\end{array}$ & 50,16 & 51,17 \\
\hline
\end{tabular}

Kadar air mempunyai peranan yang besar terhadap mutu suatu produk dan mutu roti. Kualitas dipengaruhi oleh kadar air ditentukan oleh kadar air, terutama kualitas dalam bentuk stabilitas selama penyimpanan roti sebelum sampai ke konsumen. Kadar air roti yang diperoleh pada penelitian ini adalah ratarata $35,85 \%$ untuk roti dari adonan asam ragi sari mentimun dan $35,70 \%$ untuk roti dari adonan asam ragi sari ciremai. Kadar air roti ini berada pada kisaran kadar air roti secara umum. Roti yang diolah dengan tepung komposit memiliki kadar air 19,26-20,87\% (Chikwendu dan Nwamarah, 2015). Roti dengan serat tinggi dilaporkan memiliki kadar air antara 32,1-42,2\% (Yang dkk., 2016). Variasi kadar air dari produk olahan roti segar sangat tinggi. Kadar air sangat berpengaruh terhadap kelembaban dan tekstur roti. Kadar air yang rendah menyebabkan roti tekstur roti agak kering, sedangkan kadar air yang terlalu tinggi akan menyebabkan produk menjadi mudah untuk ditumbuhi mikroba pembusuk. Kadar air yang cukup pada roti menentukan daya terima, kesegaran, dan tekstur roti. Air dapat mempengaruhi sifat-sifat fisik atau adanya 
perubahan kimia seperti tekstur, kenampakan, dan cita rasa makanan selama pengolahan.

Kadar abu roti menunjukkan kandungan mineral total yang terdapat didalam roti. Pada penelitian ini roti memiliki kadar abu rata-rata $0,69 \%$ untuk roti dari adonan asam ragi sari mentimun dan $0,83 \%$ untuk roti dari adonan asam ragi sari ciremai. Hasil analisis kadar abu kedua jenis roti secara statistik $(\alpha=0,05)$ signifikan tidak berbeda nyata. Peneliti lain melaporkan roti tepung komposit dengan serat tinggi memiliki kadar abu antara $1,1-1,9 \%$ (Yang dkk., 2016) dan 1,25-1,57\% (Chikwendu dan Nwamarah, 2015). Kadar abu dari suatu bahan dapat digunakan sebagai dasar untuk pendugaan kandungan mineral yang terdapat didalam bahan. Kadar abu roti sangat dipengaruhi oleh kadar abu yang terdapat pada bahan utama pembuatan roti yaitu kadar abu dari tepung terigu. Tepung terigu memiliki kadar abu yang bervariasi dari 0,38\% hingga 1,62\% (Heshe dkk., 2015).

Kadar protein yang diperoleh pada penelitian ini adalah rata-rata $9,80 \%$ dengan standar deviasi 0,03 untuk roti dari adonan asam ragi sari mentimun dan 9,74\% dengan standar deviasi 0,14 untuk roti dari adonan asam ragi sari ciremai dapat dilihat pada tabel 6 . Kadar protein roti berada pada kadar protein rata-rata umumnya seperti dilapokan bahwa roti mengandung protein dengan kisaran 8,4\% hingga 12,7\% (Yang dkk., 2016). Kadar protein yang terdapat pada roti sebagian besar diperoleh dari kadar protein tepung terigu dan kadar protein telur. Tepung terigu yang digunakan pada penelitian ini adalah tepung terigu protein tinggi dengan kadar protein ratarata $12,0-13,5 \%$. Tepung terigu protein rendah hingga tepung terigu protein tinggi memiliki kadar air berkisar antara 10,48-12,30\%, kadar abu 0,38-1,62\%, kadar protein 7,13-14,40\%, kadar lemak 1,32-1,82\% (Heshe, dkk, 2016).

Kadar lemak roti yang diperoleh pada penelitian ini merupakan kadar lemak kasar. Kadar lemak yang didapatkan dari hasil ekstraksi lemak oleh pelarut heksan. Metode ini didasarkan pada pelarut yang dibiarkan kontak dengan sampel roti yang telah dibungkus dengan kertas saring. Ekstraksi yang dilakukan selama kurang lebih 6 jam agar kontak antara pelarut dengan sampel secara berulang sehingga lemak dapat terekstrak maksimal. Selanjutnya pelarut diuapkan untuk mendapatkan endapan lemak. Hasil penentuan kadar lemak roti adalah rata-rata 3,49\% $\pm 0,13$ untuk roti dari adonan asam ragi sari mentimun dan $2,56 \%+0,21$ untuk roti dari adonan asam ragi sari ciremai.

Hasil uji hipotesis statistik terhadap kadar zat gizi meliputi kedua sampel roti yang diolah menggunakan adonan asam dari ragi sari mentimun (roti $\mathrm{M}$ ) dan sari ciremai (roti C) menunjukkan hasil uji hipotesis statistik signifikan tidak berbeda nyata $(\alpha=0,05)$ untuk kadar air roti. Kandungan zat gizi yang berbeda pada buah mentimun dan buah ciremai tidak berpengaruh nyata pada pertumbuhan mikroba yang dibutuhkan untuk pembentukan adonan asam.
Uji kualitas organoleptik dilakukan pada 9 skala penilaian untuk aspek aroma, penampakan, warna dan tekstur. Skala penilaian untuk aspek aroma yaitu spesifik jenis roti bun, tidak ada aroma yang mengganggu; spesifik jenis roti bun agak berkurang, tidak ada aroma yang mengganggu; spesifik jenis roti bun berkurang, tidak ada aroma yang mengganggu; spesifik jenis roti bun hilang, ada sedikit aroma yang mengganggu; spesifik jenis roti bun hilang, aroma yang mengganggu bertambah; spesifik jenis roti bun hilang, aroma yang mengganggu makin bertambah; aroma asam dan tajam; sangat asam dan tajam. Hasil uji kualitas aroma roti bun disajikan pada gambar 3 .

Berdasarkan skala penilaian tersebut sebagian besar panelis menilai aroma spesifik roti agak berkurang untuk kedua jenis roti bun (nilai skor 8), tetapi tidak ada aroma yang mengganggu. Sebagian panelis (10-20\%) menilai roti bun yang diolah menggunakan adonan asam sari ciremai dan sari mentimun memiliki aroma spesifik roti hilang, ada sedikit aroma mengganggu. Pengolahan roti menggunakan metode adonan asam secara umum memberikan pengaruh terhadap kualitas akhir dari roti yang dihasilkan. Metode adonan asam menyebabkan transformasi lipid, makromolekul dan beberapa senyawa phytochemical seperti asam fenolik, folat dan senyawa bioaktif terkonjugasi gula (Koistinen dkk., 2018).

Skala penilaian penampakan roti adalah penampakan menarik; spesifik jenis roti bun; cukup menarik spesifik jenis roti bun; cukup menarik, spesifik jenis roti bun berkurang; cukup menarik, spesifik jenis roti bun hampir hilang; kurang menarik, spesifik jenis roti bun hilang; tidak menarik, ada sedikit warna mengganggu; tidak menarik, warna remah kusam; sangat tidak menarik, warna remah kusam; sangat tidak menarik, warna remah sangat kusam.

Hasil penilaian terhadap penampakan roti bun adalah pada skala penampakan menarik, spesifik roti bun (nilai skor 9); penampakan cukup menarik , spesifik roti bun (nilai skor 8); penampakan cukup menarik, spesifik roti bun berkurang (nilai skor 7); cukup menarik, spesifik roti bun hampir hilang (nilai skor 6). Penampakan cukup menarik, spesifik roti bun merupakan skala penilaian terbanyak yang dipilih oleh panelis untuk kedua jenis roti. Spesifik penampakan bentuk roti bun yang diamati adalah bulat dengan kulit atas kuning kecoklatan.

Rasa manis roti bun dinilai dengan skala penilaian manis, spesifik jenis roti bun; agak manis, spesifik jenis roti bun; agak manis, spesifik jenis roti bun berkurang; kurang manis, spesifik jenis berkurang; kurang manis, spesifik jenis berkurang; manis hampir hilang, spesifik jenis hilang; manis hilang, spesifik jenis hilang; tidak manis, tidak enak; sangat tidak enak. Skala penilaian yang paling banyak diberikan oleh panelis untuk kualitas rasa kedua jenis roti adalah agak manis, spesifik jenis roti bun dengan nilai skor 8. Roti dari adonan asam ragi sari mentimun lebih banyak dipilih untuk aspek rasa agak manis spesifik jenis roti 
bun dibandingkan roti dari adonan asam ragi sari ciremai. Rasa manis roti diperoleh dari jumlah gula yang digunakan pada pembuatan roti, adonan roti bun menggunakan gula pasir sebanyak $9 \%$ dari total bahan.

Tekstur roti bun dengan skala sangat empuk, remah halus kulit luar tipis; empuk, remah halus kulit luar tipis; agak empuk, remah halus kulit luar tipis; agak empuk, remah halus kulit luar agak tebal; kurang empuk, remah halus kulit luar tipis; tidak empuk, remah agak halus kulit luar tipis; tidak empuk, remah agak halus kulit luar agak tebal; tidak empuk, remah agak kasar kulit luar agak tebal; tidak empuk, remah kasar kulit luar tebal. Roti dengan tekstur agak empuk, remah halus, kulit luar agak tipis merupakan skala penilaian untuk tekstur roti dari adonan asam ragi sari mentimun. Sedangkan roti dari adonan asam ragi sari ciremai memiliki tekstur agak empuk, remah halus dan kulit luar agak tebal.



Gambar 3. Hasil Analisis Mutu Hedonik Roti Bun yang Diolah dengan Adonan Asam Ragi Sari Mentimun dan Sari Ciremai.

Perbedaan kualitas organoleptik dari roti banyak dipengaruhi oleh proses yang dilakukan dalam pengolahan roti. Pengolahan roti dari adonan dengan total waktu fermentasi yang cukup lama dibandingkan proses fermentasi menggunakan ragi instan menyebabkan aroma yang terbentuk selama proses fermentasi sangat berbeda. Tekstur roti yang diperoleh juga sangat ditentukan oleh kadar air roti. Kadar air roti dipengaruhi oleh penguapan yang tejadi pada saat proses pembakaran roti, jenis oven dan kondisi oven yang digunakan. Pada saat pembakaran suhu air meningkat yang mengakibatkan ikatan hidrogen akan putus dan tekanan uap air melebihi tekanan atmosfer, akibatnya molekul terlepas dari permukaan roti dan roti bagian luar menjadi lebih cepat keras.

Pada proses pengolahan roti setelah adonan asam dicampur dengan bahan lainnya hingga kalis dilakukan tahap pengembangan adonan. Pemanggangan dalam oven yang merupakan titik kritis yang dapat mempengaruhi sifat roti yang nantinya akan mempengaruhi kualitas produk akhir roti.

Secara statistik hasil uji organoleptik pada tingkat kesalahan 0,05 tidak menunjukkan hasil yang berbeda nyata pada aspek aroma, penampakan, rasa dan tekstur. Uji hipotesis menggunakan uji T-test, paired two sample for mean menunjukkan nilai uji $\mathrm{T}$ statistik lebih kecil dari nilai $\mathrm{T}$ kritis, yang artinya hipotesis nol diterima yaitu tidak ada perbedaan kualitas organoleptik dari roti bun yang diolah menggunakan adonan asam ragi mentimun dibandingkan dengan roti bun yang diolah menggunakan adonan asam ragi ciremai. 


\section{KESIMPULAN}

Kadar air roti yang diperoleh pada penelitian ini adalah rata-rata $35,85 \%$ untuk roti dari adonan asam ragi sari mentimun dan $35,70 \%$ untuk roti dari adonan asam ragi sari ciremai. Kadar abu roti menunjukkan kandungan mineral total yang terdapat didalam roti. Roti memiliki kadar abu rata-rata $0,69 \%$ untuk roti dari adonan asam ragi sari mentimun dan $0,83 \%$ untuk roti dari adonan asam ragi sari ciremai. Kadar protein yang adalah rata-rata $9,80 \%$ dengan standar deviasi 0,03 untuk roti dari adonan asam ragi sari mentimun dan $9,74 \%$ dengan standar deviasi 0,14 untuk roti dari adonan asam ragi sari ciremai. Kadar lemak roti adalah rata-rata $3,49 \% \pm 0,13$ untuk roti dari adonan asam ragi sari mentimun dan 2,56\%+0,21 untuk roti dari adonan asam ragi sari ciremai. Kadar zat gizi kedua sampel roti yang diolah menggunakan adonan asam dari ragi sari mentimun dan sari ciremai menunjukkan hasil uji hipotesis statistik signifikan tidak berbeda nyata $(\alpha=0,05)$. Kandungan zat gizi yang berbeda pada buah mentimun dan buah ciremai tidak berpengaruh nyata pada pertumbuhan mikroba yang dibutuhkan untuk pembentukan adonan asam.

Berdasarkan skala penilaian uji organoleptik aspek aroma sebagian besar panelis menilai aroma spesifik roti agak berkurang untuk kedua jenis roti bun, bahkan penilaian untuk roti yang diolah menggunakan adonan asam sari ciremai oleh seorang panelis ahli adalah aroma spesifik roti hilang, ada sedikit aroma mengganggu. Penampakan cukup menarik, spesifik roti bun merupakan skala penilaian terbanyak yang dipilih oleh panelis. Roti dari adonan asam ragi sari mentimun lebih banyak dipilih untuk aspek rasa agak manis spesifik jenis roti bun dibandingkan roti dari adonan asam ragi sari ciremai. Roti dengan tekstur agak empuk, remah halus, kulit luar agak tipis merupakan skala penilaian untuk tekstur roti dari adonan asam ragi sari mentimun. Sedangkan roti dari adonan asam ragi sari ciremai memiliki tekstur agak empuk, remah halus dan kulit luar agak tebal. Secara statistik $(\alpha=0,05)$ hasil uji organoleptik tidak menunjukkan hasil yang berbeda nyata pada aspek aroma, penampakan, rasa dan tekstur.

\section{SARAN}

Profil metabolit sekunder serta karakteristik pertumbuhan mikroba selama fermentasi sari buah dan selama proses pembentukan adonan asam merupakan salah satu faktor yang mempengaruhi kualitas roti bun yang dihasilkan, sehingga perlu dilakukan proses penelitian lanjutan untuk mengamati profil metabolit sekunder.

\section{DAFTAR PUSTAKA}

Ayele, H.H., G. Bultosa, T. Abera, dan T. Astatkie. 2017. Nutritional and sensory quality of wheat bread supplemented with cassava and soybean flours. Cogent Food \& Agriculture. 14(1):1-13.
Bhatt, S.M. dan R.K. Gupta. 2015. Bread ( composite flour ) formulation and study of its nutritive, phytochemical and functional properties. 4(2):254268.

Bw, A., N. Nwachoko, dan I. Gn. 2017. Biochemistry \& analytical biochemistry nutritional value of cucumber cultivated in three selected states of. 6(3):19-21.

Chavan, R.S. dan S.R. Chavan. 2011. Sourdough technology-a traditional way for wholesome foods : a review. 10(Pedersen 1994):170-183.

Chikwendu, J.N. dan J.U. Nwamarah. 2015. Determination of nutrient composition and organoleptic evaluation of bread produced from composite flours of wheat and beans. (December)

Goraya, R. K. dan U. Bajwa. 2015. Enhancing the functional properties and nutritional quality of ice cream with processed amla (Indian gooseberry ). 52(December):7861-7871.

Heshe, G.G., G.D. Haki, dan A.Z. Woldegiorgis. 2015. Effect of conventional milling on the nutritional value and antioxidant capacity of wheat types common in ethiopia and a recovery attempt with bran supplementation in bread

Koistinen, V.M., O. Mattila, K. Katina, K. Poutanen, A. Aura, dan K. Hanhineva. 2018. Metabolic profiling of sourdough fermented wheat and rye bread. Scientific Reports. 1-11.

Lombardi, A. dan B. Pecorino. 2016. Evaluating low sodium content in food: the willingness to pay for salt-reduced bread the willingness to pay for saltreduced bread, a case study. (December)

Ma'aruf, A., Z. Aisyikee, A.Sahilah, dan A. .Khan. 2011. Leavening ability of yeast isolated from different local fruits in bakery product. 40(12):1413-1419.

Mansooreh, S., M. Aalami, dan A. Mahoonak. 2017. Effect of exopolysaccharide extracted from iranian kefir grains on bread quality properties of medium protein wheat. 4:152-159.

Muthoharoh, D.F. dan A. dan Sutrisno. 2017. Pembuatan roti tawar bebas gluten berbahan baku tepung garut, tepung beras, dan maizena (konsentrasi glukomanan dan waktu proofing ). 5(2):34-44.

Survase, A. G., D. T. Bornare, dan K. P. Babar. 2018. Effect of indian gooseberry juice on physicochemical and sensory quality characteristics of soybean based yoghurt. 6(3):3296-3300.

Therdthai, N. 2015. Effect of addition of sourdough on physicochemical characteristics of wheat and rice flour bread effect of addition of sourdough on physicochemical characteristics of wheat and rice flour bread. (March)

Wulandari, E. 2017. Karakteristik roti komposit ubi jalar ungu dengan penambahan $\alpha$-amilase dan glukoamilase characteristic of composite bread $\mathrm{w}$ ith $\alpha$-amylase and glucoamylase. 1:2-7.

Yang, T., H.A. Mudawi, M.O. Rasha, dan A.H. Ahmed. 2016. Chemical composition and functional 
properties of wheat bread containing wheat and legumes bran. (September)

Yenrina, R. 2015. Metode Analisis Bahan Pangan Dan Komponen Bioaktif. Padang: Andalas University Press. 